\title{
David Greenwood
}

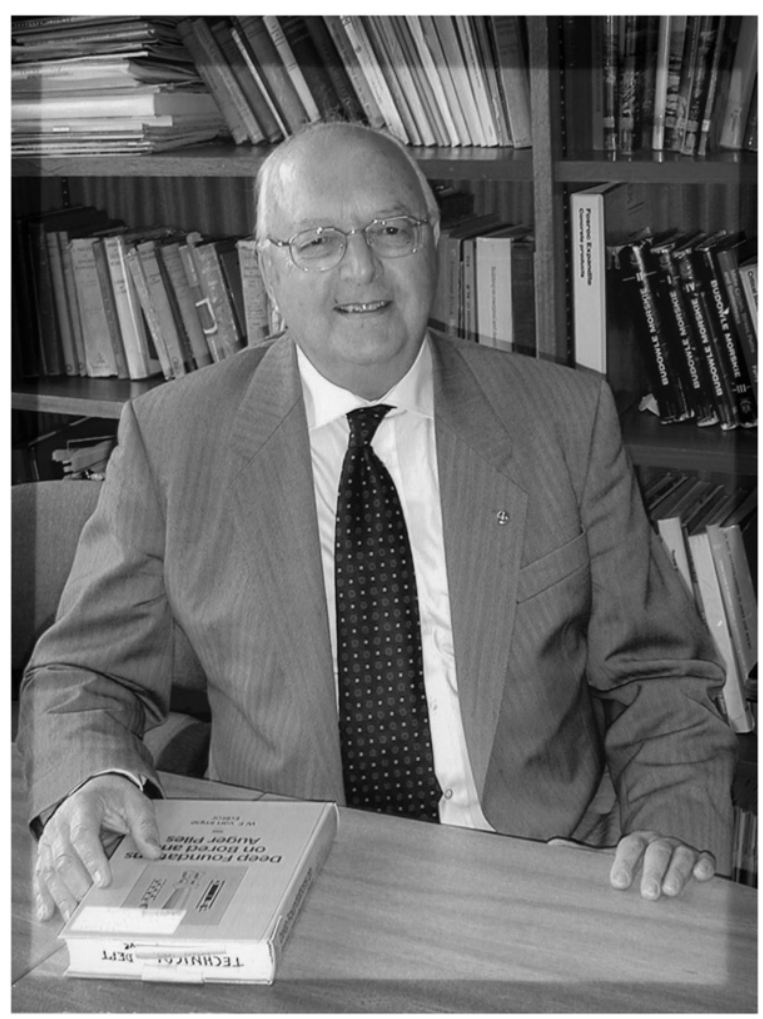

David Arthur Greenwood (1933-2020)

David Greenwood was an outstanding geotechnical engineer who combined enormous practical ground treatment experience with an unbounded enthusiasm for research and innovation. In his long and distinguished working life he was involved with ground improvement aspects of numerous geotechnical projects throughout the UK and in many parts of the world.

David was a Yorkshireman through and through. He was born in Thirsk in 1933, grew up there and studied civil engineering at the University of Leeds, obtaining a first class degree in 1953. He stayed on at Leeds to undertake post-graduate studies on flow in unsaturated soils above the phreatic surface, gaining a PhD in 1958. During this time he played hockey for Yorkshire. In 1956 he joined the company Cementation and Piling Foundations in Doncaster, UK, who were concerned with shaft sinking, grouting of old coal workings and tunnelling; this was the beginning of his lifelong career with Cementation. Initially he focused on research aspects of grouting of soils, applying himself to the improvement of cement grouts, but soon he became the manager of Cementation's site investigation department in Doncaster, running contracts and a soils laboratory.

In 1959 he became a process design engineer in Cementation's London office, from where he became very actively involved in many kinds of ground treatment processes for a wide range of prestigious and challenging geotechnical projects, both in the UK and overseas. He rapidly developed world-leading expertise in grouting, notably on chemical grouting for the Dartford tunnel, constructed in fissured chalk under compressed air, as well as for the Blackwall tunnel, London Bridge and Green Park stations for London Underground, and the Cairo sewer tunnel.

David also became involved with many other geotechnical processes: diaphragm walls for the Matahina dam in New Zealand and the Coolmunda dam in Queensland, Australia; vacuum dewatering for a drift construction at Medomsley colliery in County Durham; and jetting and grouting for the Kariba dam. He played a key role in Cementation's invention of jet grouting and was closely involved in their first jet grouting project at Newquay in 1962.

He became manager of Cementation's vibroflotation department in 1964, a position he held for 6 years, during which he was responsible for a rapid expansion of its business. David was always keen to try new ground treatment processes. He developed reliable analysis and control methods for vibroflotation to densify sandy soils and he oversaw deep ground compaction and stone column processes to improve foundations for a wide range of projects in the UK and overseas: ICI Ardeer, Scotland, Teesport refinery tanks, an ore stockyard in Wales for British Steel; Marala barrage in Pakistan, oil tanks in Venice, and buildings in Jamaica and Brunei. David became particularly interested in the development of compaction grouting, involving thick, cementitious mortar mixes which were injected into the ground to combat and rectify settlement. He applied this technology to Daura pumping station in Iraq, shaft construction in Rochdale and various masonry and brick buildings.

David became a director of Cementation Ground Engineering in 1970, where he enthusiastically and very effectively introduced innovations and technologies to mining, piling, ground engineering and research aspects of the company's activities. He was responsible for the technical and commercial viability of many projects, including general mine filling, dam cut-off grouting, tunnel grouting, ground anchorages, gunite and miscellaneous related activities. Notable projects included the Ninian central offshore platform in 1977, for which topsides compression members were stiffened by pneumatic stowing of $25-100 \mathrm{~mm}$ aggregate, which was subsequently grouted in situ; the Bishopsbriggs quarry filling in 1979, involving innovative sluicing of infill to cavernous mines; and soil nailing of a $21 \mathrm{~m}$ high face in St Peter Port, Guernsey.

His wide experience of geotechnical processes brought him into demand in many countries. He assisted project teams for major tenders, for example with Gammon, Hong Kong, on Singapore Metro contracts, and he worked on the Jubail, Saudi Arabia seawater pumping station, involving specification, negotiation and contract surveillance for 1000 ground anchorages. Among David's many and diverse geotechnical consulting activities, examples included advising on jetgrouting stabilisation of Kingston Bridge in Glasgow, investigating causes of a compressed air 'blow' on the Cairo wastewater project and devising potential means of recovering a flooded mine under $500 \mathrm{~m}$ of water head in Namibia. He became a world-renowned expert on mine construction and recovery after collapse or flooding, being asked to advise on projects in the UK, South Africa, USA and New Zealand. 
On his retirement from Cementation in 1996, David continued to be very active. He became an associate with Geotechnical Consulting Group (GCG) and continued to be in demand as a leading expert on geotechnical processes. A few years earlier he had worked closely with GCG on their innovative proposals for compensation grouting to protect the Victory arch, Waterloo and City Line and Elizabeth House from settlement during construction of the $10 \mathrm{~m}$ dia. Waterloo escalator tunnel for London Underground. David was instrumental in developing the novel method specification. The success of that project resulted in widespread adoption of compensation grouting for the construction of the Jubilee line extension, including the protection of Big Ben. All of his colleagues working with David on that innovative specification for the first compensation grouting project in the UK remember how he treated everyone as an equal, was extremely self-deprecating about his own input, generous in acknowledging everyone's contributions and more than patient when explaining when they had clearly got things wrong. Although the specification had all the hallmarks of David's drafting skills, the fact that it felt it was a joint effort was entirely due to his inclusive attitude to collaboration, for which he was so well known and admired.

Some years later, David assisted GCG(Asia) with solving challenging grouting problems on several projects in many different parts of the world. His products were always the same: scientifically rigorous with a meticulous interrogation of data, beautifully written summaries of his work with a view to explaining complicated physical and chemical processes clearly to a layperson, and always focused on the practicalities of applying science to a construction process that is commonly (and often unfairly in his view) referred to as 'a black art'.

David devoted a considerable amount of his energies to the geotechnical profession and to academic research projects. He was a fellow of the Institution of Civil Engineers (ICE), an ICE council member and deputy chairman of its ground board. He was a visiting professor at the University of Newcastle, a member of Surrey University's civil engineering advisory board, and chair of Ciria's geotechnical advisory committee and the Association of Geotechnical Specialists. A notable example of his strong interest and support for geotechnical research was his membership of the Science and Engineering Research Council (now EPSRC) geotechnics steering group in 1986-1991; in this role he was a particularly strong advocate for the field research site at Bothkennar, at which soft clays were investigated, sampled and tested using state-of-the-art techniques. David was a member of the Géotechnique advisory panel between 1990 and 1993.

His long and illustrious career as a world-leading expert on ground treatment and geotechnical processes was fittingly recognised in 1993 by the British Geotechnical Association's highest award, the Skempton gold medal, for his lifelong contributions to the practice of geotechnical engineering.

David was a great inspiration, nationally and internationally, to many young geotechnical practitioners. He was a genuine pleasure to work with, always smiling, at all times the archetypal gentleman and scholar, excellent and engaging company.

Rab Fernie, formerly Cementation Ground Engineering, London, UK

Tom Henderson, Golder Associates (Hong Kong), formerly GCG (Asia), Hong Kong, China

David Hight, Geotechnical Consulting Group, London, UK Robert Mair, University of Cambridge, Cambridge, UK

\section{SELECTED BIBLIOGRAPHY}

Coe, R. H., Greenwood, D. A., Kleina, R., \& McAnally, C. J. (1994). A review of grouting on the Greater Cairo wastewater project. In Grouting in the ground: proceedings of conference organised by the Institution of Civil Engineers (ed. A. L. Bell), pp. 163-182. London, UK: Thomas Telford.

Greenwood, D. A. (1962) Discussion on 'An introduction to alluvial grouting'. Proc. Instn Civ. Engrs 23, No. 4, 705-772.

Greenwood, D. A. (1964) Discussion contribution: Formulation and application of grouts containing clay. In Grouts and drilling muds in engineering practice, pp. 166-167. London, UK: Butterworths.

Greenwood, D. A. (1968) Discussion contribution: Foundations for storage tanks on reclaimed land at Teesmouth. Proc. Instn Civ. Engrs 39, No 4, 585-601.

Greenwood, D. A. (1970) Mechanical improvement of soils below ground surface. Ground engineering: proceedings of a conference organised by the Institution of Civil Engineers, pp. 11-20. London, UK: Institution of Civil Engineers.

Greenwood, D. A. (1974) Differential settlement tolerances of cylindrical steel tanks for bulk liquid storage. In Settlement of structures: conference organised by the British Geotechnical Society, pp. 361-367. London, UK: Pentech Press.

Greenwood, D. A. (1975) Vibroflotation - rationale for design and practice. In Methods of treatment of unstable ground (ed. F. G. Bell), pp. 189-209. Sevenoaks, UK: NewnesButterworths.

Greenwood, D. A. (1976). Discussion contribution: Vibro-flotation compaction in non-cohesive soils. In Ground treatment by deep compaction, pp. 107-109. London, UK: Institution of Civil Engineers.

Greenwood, D. A. (1976) Discussion contribution: Stone columns in soft cohesive soils. In Ground treatment by deep compaction, pp. 123-125. London, UK: Institution of Civil Engineers.

Greenwood, D. A. (1984) Re-levelling a gas holder at Rhyl. Q. J. Engng Geol. 17, No. 4, 319-326.

Greenwood, D. A. (1985) Underpinning by grouting. Building appraisal, maintenance and preservation, symposium, Bath, UK, pp. $97-112$.

Greenwood, D. A. (1986) Discussion contribution. In Groundwater in engineering geology: proceedings of the 21st annual conference of the Engineering Group of the Geological Society (eds J. C. Cripps, F. G. Bell and M. G. Culshaw), pp 549-552. London, UK: Geological Society.

Greenwood, D. A. (1986) Discussion contribution: Settlement of foundations on sand and gravel. Proc. Instn Civ. Engrs, Pt 1 80, No. 6, 1625-1648.

Greenwood, D. A. (1987) Simple techniques of ground improvement with cement. In Foundations and tunnels - 87: proceedings of the international conference on foundations and tunnels, vol. 2, pp. 8-19. Edinburgh, UK: Engineering Technics Press.

Greenwood, D. A. (1987) Underpinning by grouting. Ground Engng 20, No. 3, 21-30.

Greenwood, D. A. (1989) Sub-structure techniques for excavation support. In Economic construction techniques: proceedings of the conference economic construction techniques: temporary works and their interaction with permanent works, pp. 17-40. London, UK: Thomas Telford.

Greenwood, D. A. (1991). Load tests on stone columns. In Deep foundation improvements: design, construction and testing (eds M. I. Esrig and R. C. Bachus), ASTM STP 1089, pp. 148-171. West Conshohocken, PA, USA: American Society for Testing and Materials.

Greenwood, D. A. (1992) Fundamental basis of grout injection for ground treatment, draft document, Research Project 451. London, UK: Construction Industry Research and Information Association (Ciria).

Greenwood, D. A. (1992) Preface: Bothkennar soft clay test site: characterization and lessons learned. Géotechnique 42, No. 2, 161-162, https://doi.org/10.1680/geot.1992.42.2.161.

Greenwood, D. A. (1994) Keynote paper. Engineering solutions to groundwater problems in urban areas. In Groundwater problems in urban areas (ed. W. B. Wilkinson), pp. 369-387. London, UK: Thomas Telford.

Greenwood, D. A. (1994) Report on Session 1: Permeation grouting. In Grouting in the ground: proceedings of the conference organised by the Institution of Civil Engineers (ed. A. L. Bell), pp. 71-90. London, UK: Thomas Telford. 
Greenwood, D. A. (1995) Slurry walls as barriers to the flow of pollutant liquids and gas: introductory notes. In Contaminated land: geotechnical remediation processes: informal discussion, pp. 1-2. London, UK: ICE Ground Board.

Greenwood, D. A. (1997) Discussion contribution: Standards of practice and general discussion - Session 8. In Ground anchorages and anchored structures: proceedings of the international conference organised by the Institution of Civil Engineers (ed. G. S. Littlejohn), pp. 537-629. London, UK: Thomas Telford.

Greenwood, D. A. (1997). Fundamental basis of grout injection for ground treatment, Ciria Project Report 62. London, UK: Construction Industry Research and Information Association (Ciria).

Greenwood, D. A. (1998) Speculations on methods of stabilizing slopes. Ground Improvement 2, No. 3, 103-123, https://doi.org/ 10.1680/gi.1998.020302.

Greenwood, D. A. (2001) Discussion: Analysis of single-fluid jet grouting. Géotechnique 51, No. 10, 905-906, https://doi.org/ 10.1680/geot.2001.51.10.905.

Greenwood, D. A. (2001) Discussion: Group effects in stone column foundations: model tests. Géotechnique 51, No. 7, 649-664, https://doi.org/10.1680/geot.2001.51.7.649.

Greenwood, D. A. (2005) Discussion: Laboratory investigation of multiple grout injections into clay. Géotechnique 55, No. 3, 257-258, https://doi.org/10.1680/geot.2005.55.3.257.

Greenwood, D. A. (2006) Discussion: An advanced experimental set-up for studying a monodirectional grout injection process. Ground Improvement 10, No. 3, 133-134, https://doi.org/ 10.1680/grim.2006.10.3.133.

Greenwood, D. A. (2008) Discussion: Theoretical modelling of jet grouting. Géotechnique 58, No. 6, 533-535, https://doi.org/10. 1680/geot.2008.58.6.533.

Greenwood, D. A. (2009) Discussion: Design of jet-grouting cut-offs. Proc. Instn Civ. Engrs - Ground Improvement 162, No. 1, 47-50, https://doi.org/10.1680/grim.2009.162.1.47.

Greenwood, D. A. \& Chapman, T. J. P. (1992) Informal Discussion: Grouting processes with emphasis on control of foundation settlements. Proc. Instn Civ. Engrs - Structs Buildings 94, No. 3, 375-377, https://doi.org/10.1680/istbu.1992.20298.

Greenwood, D. A. \& Hutchinson, M. T. (1982) Squeeze grouting unstable ground in deep tunnels. In ASCE speciality conference on grouting in geotechnical engineering (ed. W. H. Baker), pp. 631-651. New York, NY, USA: American Society of Civil Engineers (ASCE).

Greenwood, D. A. \& Kirsch, K. (1984) Specialist ground treatment by vibratory and dynamic methods. In Piling and ground treatment: proceedings of the international conference on advances in piling and ground treatment for foundations organised by the Institution of Civil Engineers (eds S. Thorburn, R. W. Cooke and A. Fawcett), pp. 17-45. London, UK: Thomas Telford.

Greenwood, D. A. \& McNulty, T. A. (1987) Technical Note. Ground anchorages: shear tube anchors. Proc. Instn Civ. Engrs 82, No. 3, 591-599, https://doi.org/10.1680/iicep.1987.321.
Greenwood, D. A. \& Raffle, J. F. (1964). Formulation and application of grouts containing clay. Grouts and drilling muds in engineering practice: symposium organised by the British National Society, pp. 127-130. London, UK: Butterworths.

Greenwood, D. A. \& Thomson, G. H. (1983) ICE works construction guides: ground stabilisation: deep compaction and grouting. London, UK: Thomas Telford.

Greenwood D. A., Hutchinson, M. T., Rooke J. (1987) Chemical injection to stabilise water logged sand during tunnel construction for Cairo wastewater project. IX European conference on soil mechanics and foundation engineering, Dublin, Ireland, vol. 1, pp. $157-164$.

Greenwood, D. A., Lord, J. A. \& Haimoni, A. M. (1994) Settlement correction by intrusion grouting in organic clays: a dubious success. Grouting in the ground: proceedings of the conference organised by the Institution of Civil Engineers (ed. A. L. Bell), pp. 361-373. London, UK: Thomas Telford.

Hughes, J. M. O., Withers, N. J. \& Greenwood, D. A. (1975) A field trial of the reinforcing effect of a stone column in soil. Géotechnique 25, No. 1, 31-44, https://doi.org/10.1680/geot. 1975.25.1.31.

Hughes, J. M. O., Withers, N. J. \& Greenwood, D. A. (1976) A field trial of the reinforcing effect of a stone column in soil. In Ground treatment by deep compaction, pp. 31-44. London, UK: Institution of Civil Engineers.

Littlejohn, G. S., Greenwood, D. A., Hanna, T. H., Michell, J. M. \& Dawson, A.R. (1985) Informal discussion. Ground anchorages: case histories. Proc. Instn Civ. Engrs 78, No. 6, 1500-1503, https://doi.org/10.1680/iicep.1985.1073.

Littlejohn, G. S., Mitchell, J. M., Jones, D. L., Greenwood, D. A., Barley, A. D. \& Hellings J. E. (1990) BS 8081 ground anchorages: a new British Standard code of practice. Half-day meeting - Ground Engineering Group. Proc. Instn Civ. Engrs 88, No. 6, 1117-1121, https://doi.org/10.1680/iicep. 1990.11641.

Raffle, J. F. \& Greenwood, D. A. (1961) The relation between the rheological characteristics of grouts and their capacity to permeate soil. Proceedings of the 5th international conference on soil mechanics and foundation engineering, Paris, France, vol. 2, pp. 789-793.

Thorburn, S., Greenwood, D A. \& Fleming, W. G. K. (1993) The response of sands to the construction of continuous flight auger piles. Deep foundations on bored and auger piles, BAP II: proceedings of the 2 nd international geotechnical seminar, Ghent, Belgium, pp. 429-443.

Vaughan, P. R., Kennard, R. M. \& Greenwood, D. A. (1983) Squeeze grouting of stiff fissured clay after a tunnel collapse. Proceedings of the 8th European conference on SMFE, Helsinki, Finland, vol. 1-3, pp. 171-177.

Watt, A. J., deBoer, J. J. \& Greenwood, D. A. (1967) Loading tests on structures founded on soft cohesive soils strengthened by compacted granular columns. Proceedings of the 3rd Asian conference on soil mechanics and foundation engineering, Haifa, Israel, vol. 1, pp. 248-251. 